\title{
AOR
}

Selected Papers of \#AolR2020:

The $21^{\text {st }}$ Annual Conference of the

Association of Internet Researchers

Virtual Event / 27-31 October 2020

\section{fncKING WITH WHITE FRAMES: Teejayx6 SCAM RAPS THE DIGITAL}

Robert Tynes

Bard Prison Initiative, Bard College

Alex Pearl

Bard Prison Initiative, Bard College

Teejayx6 lays it all out:

First you gotta find a site for you to load on

You gon' hit the Bitcoin, you can't be petty though

Put your money in, can't be nothing under a hundred though

If you want to hit for more big shit, put a hundred mo'

Log into your site and it's going to tell you which address to load

Then you type that same address on the bitcoin machine

Put the right address, it should pop up green

Then from there, you are done with that bitcoin machine

Hop in your whip, but you gotta play it low key

Cause remember bro, you just loaded up on kerm

Go to Starbucks, but make sure you brung your computer

Go on the internet and log into ya site

Wait 10 minutes and the money should be on your account...

(from Swipe Lessons)

Teejayx6 is a scam rapper from Detroit, who puts to shame the notion that the internet is a cyberspace frontier where you can be all you wanna be. Instead, he presents it as a rich field to be harvested, and through his music provides insights about race and the internet. Ever since Kolko et al. (2000) published Race in Cyberspace, internet studies has tried to tease out how race plays out on the internet. But, as scholar Jessie Daniels

Suggested Citation (APA): Tynes, R and Pearl, A. (2020, October 28-31). fncKING WITH WHITE FRAMES: Teejayx6 SCAM RAPS THE DIGITAL. Paper presented at AoIR 2020: The $21^{\text {th }}$ Annual Conference of the Association of Internet Researchers. Virtual Event : AolR. Retrieved from http://spir.aoir.org. 
(2012) shows, the field has come up way short. Maybe that's because academics are too focused on what's going on "in there" with race. There's too much of a focus on the traditional analyses of representations of blackness, or of browness, or of yellowness. Instead, in line with Daniels (2012) urgings, we should be figuring out how whiteness is embedded, so deeply, in the internet. And so, we ask: What does Teejayx6's scam rap, and the scam rap of his predecessors, tell us about whiteness and the internet? Teejayx6 lyrics and online interviews help expose whiteness mythologies entrenched in internet discourse. We see how the open frontier of cyberspace masks territorialization; how identity fluidity is more of an elite fantasy than a pluralistic fact; and, how the promise of leisure and prosperity is false consciousness at best.

Scam rap is a hip hop song that talks about using the internet to steal credit card numbers and identities, Bitcoins, whatever, so that the scammer can then go buy offline merchandise. Rappers who scam rap include: A\$AP Rocky, City Girls, Guapdad 4000, Money Man, the Pop Out Boyz, Band Gang, Kasher Quon, Bossman Rich, Shred Gang Boogz, and Selfmade Kash (Fu et al. 2019). At the forward edge of scam rap stands Teejayx6, a 19 year old from the Detroit rap scene who tells the "how to":

The government tried to ban me from the dark web (Tried to ban me) I downloaded TOR browser then got back in (Back in)

Went and got a VPN (VPN)

Just bought another BIN

Imma keep searchin these bitches on my site

Till I can slide a Benz

(from "Dark Web")

With these directions and hard style rapping, Teejayx 6 helps undermine the normative, technology gatekeeping, cliché of the Black Geek (Eglash 2002); and he chips away at the "whiteness" equals "progress", "technology" and "civilization" racialized ideology lurking in new media (Hobson 2008).

Following Derrida, Teejayx6 is "destroying the concept of 'sign' and its entire logic" (p. 7, Derrida 1976) by messing with the logos of race. It is the "destruction, not the demolition but the de-sedimentation, the deconstruction, of all the significations that have their source in that of the logos" (p. 10). Teejayx6 erases the imagined solid lines between world and cyberspace, pulling the floating signifiers out into the street. He is a trickster (Radin 1988), a rapper, exploiting white tropes about blackness, using them as "metaphoric tools for expressing power" (pp. 47, Perry 2005).

But Teejayx6's sign system is less important for what it tells us about blackness, and more significant for what it exposes about whiteness. Inverting Stuart Hall's (1997) practices that sift out the black racial other from media representations, we are making visible the invisible whiteness of the internet. Dyer (1997) called out this invisibility as a white power strategy that bolstered dominance through a taken-for-granted ubiquity (also see, Sullivan 2006; Clarke and Garner 2010). This invisibility and ubiquity extends 
deeply into the internet of today. Our project (an analysis of scam rap) is not merely an academic exercise, though, it is also an attempt at "Exposing, challenging, resisting and disrupting structures of whiteness...for the purpose of dismantling the system of racial oppression" as it plays out through the internet (P. 218, Owen 2007).

Methodologically, our study utilizes frame analysis (see Goffman 1974; Entman 1993), examining scam rap lyrics, interviews with artist, and news stories about the genre. The project sifts out the white racial frames (Feagin 2013) that the internet generates, cloaks and erases. The trace of whiteness is still there, though, and scam rap can help us see that. Some of the frames include Whiteness as Property (Harris 1993), whiteness as Terror (Hooks 1997); White Spaces (Anderson 2015); the Iconic Ghetto/the Iconic Negro (Anderson 2012); and, White Fragility (DiAngelo 2018). Ultimately, Teejayx6 and other scam rappers tell us less about how blacks exist in cyberspace, and more about how the internet reinforces systemic racism and supports structural violence (Galtung 1969).

\section{References}

Anderson, Elijah (2012). "The Iconic Ghetto." The Annals of the American Academy of Political and Social Science 642: 8-24.

Anderson, Elijah (2015). "The White Space." Sociology of Race and Ethnicity 1(1): 1021.

Clarke, Simon and Steve Garner (2010). White Identities: A Critical Sociological Approach. London: Pluto Press.

Daniels, Jessie (2012). "Race and Racism in Internet Studies: A Review and a Critique." New Media \& Society, Vol. 15, No. 5: pp. 695-719.

DiAngelo, Robin (2018). White Fragility. Boston: Beacon Press.

Dyer, Richard (1997). White. London: Routledge.

Derrida, Jacques (1976). Of Grammatology. Trans. Gayatri Chakravorty Spivak. Baltimore: Johns Hopkins University Press.

Eglash, Ron (2002). "Race, Sex, and Nerds: From Black Geeks to Asian American Hipsters." Social Text 71, Vol. 20, No. 2: pp. 49-64.

Entman, R.M. (1993). "Framing: Toward clarification of a fractured paradigm". Journal of Communication. 43 (4): 51-58. 
Fu, Eddie; Russel Abad; Jacques Morel, Jr.; and Hilary Crosley Coker (2019). "Behind the Rise of 'Scam Rap'”. Genius, 17 September, 2019. Available at:

https://genius.com/a/what-is-scam-rap

Goffman, E. (1974). Frame analysis: An essay on the organization of experience. Cambridge: Harvard University Press.

Hall, Stuart (1997). "The Spectacle of the 'Other'” In Stuart Hall (Ed.), Representation: Cultural Representations and Signifying Practices. Thousand Oaks, CA: Sage Publications, pp. 223-290.

Harris, Cheryl (1993). "Whiteness as Property" Harvard Law Review, 106(8): 17071791.

Hobson, Janell (2008). "Racializing the 'digital divide' in film and new media." Feminist Media Studies, Vol. 8, No. 2: pp. 111-126.

hooks, bell (1997). "Whiteness in the Black Imagination." In Ruth Frankenburg (ed.), Displacing Whiteness. Durham, NC: Duke University Press, pp. 165-179.

Galtung, Johan (1969). "Violence, Peace, and Peace Research" Journal of Peace Research, Vol. 6, No. 3: pp. 167-191.

Kolko, Beth, Lisa Nakamura and Gilbert B. Rodman (ed.) (2000). Race in Cyberspace. New York: Routledge.

Owen, David S. (2007). "Towards a Critical Theory of Whiteness" Philosophy \& Social Criticism, Vol. 33, No. 2: pp. 203-222.

Perry, Imani (2005). Prophets of the Hood: Politics and Poetics in Hip Hop. Durham, NC: Duke University Press.

Radin, Paul (1988). The Trickster: A Study in American Indian Mythology. NY: Schocken.

Sullivan, Shannon (2006). Revealing Whiteness: The Unconscious Habits of Racial Privilege. Bloomington: Indiana University Press. 